\title{
Effects of Use and Re-Use of Selected Vegetable Oils on the Proximate, Minerals, Mineral Ratios and Mineral Safety Index of Raw and Fried Plantain Chips: Note I
}

\author{
Emmanuel Ilesanmi Adeyeye*, Adeolu Jonathan Adesina, Sulaiman Adeoye Olagboye, \\ Mercy Ayomadewa Olatunya \\ Department of Chemistry, Faculty of Science, Ekiti State University, Ado Ekiti, Nigeria \\ Email: *eiadeyeye@yahoo.com, adeolu.adesina@eksu.edu.ng, olagboyesa2009@yahoo.com, ayomadewa.olatunya@eksu.edu.ng
}

How to cite this paper: Adeyeye, E.I., Adesina, A.J., Olagboye, S.A. and Olatunya, M.A. (2019) Effects of Use and Re-Use of Selected Vegetable Oils on the Proximate, Minerals, Mineral Ratios and Mineral Safety Index of Raw and Fried Plantain Chips: Note I. Journal of Agricultural Chemistry and Environment, 8, 92-106.

https://doi.org/10.4236/jacen.2019.82008

Received: March 22, 2019

Accepted: May 27, 2019

Published: May 30, 2019

Copyright $\odot 2019$ by author(s) and Scientific Research Publishing Inc. This work is licensed under the Creative Commons Attribution International License (CC BY 4.0).

http://creativecommons.org/licenses/by/4.0/

\begin{abstract}
Raw and fried plantain chips obtained from the use and re-use of olive, refined palm olein and coconut oils were investigated for the proximate, mineral compositions, computed mineral ratios and the mineral safety index using standard analytical methods. For the selected oils (both use and re-use): first and second re-use and the fresh plantain chips (unprocessed plantain chips; UPC) had the following range results: proximate composition (\%) (moisture: 8.20 - 12.3, crude protein: $9.70-8.60$, fat: 7.40 - 12.9, fibre: 3.50 - 4.90, ash: 2.80 - 3.80 and carbohydrates: 63.5 - 64.8), \% energy contributions (PEC: 63.4 - 70.8, PEF: 20.2 - 28.6, PEP: 8.03 - 9.66, UEDP: 4.49 - 5.08). The mineral composition $(\mathrm{mg} / 100 \mathrm{~g})$ of the samples had the following greater than 80.0: $\mathrm{Ca}, \mathrm{Mg}, \mathrm{K}$ and $\mathrm{P} ; \mathrm{Fe}, \mathrm{Cu}, \mathrm{Mn}$ and $\mathrm{Zn}$ recorded values ranging between 1.00 and 4.00; $\mathrm{Co}$, Se and $\mathrm{Ni}$ had their concentrations between 0.00 and 0.0363 whereas $\mathrm{Pb}$ and $\mathrm{Cd}$ recorded levels lower than 0.0006. In the mineral ratios, only $\mathrm{K} /(\mathrm{Ca}+\mathrm{Mg})$ values fell within the acceptable ideal range. No MSI aberration was observed for the minerals from all the samples obtained from the various oils. The chi-square analysis showed that on parameter wise comparisons, there were no significant differences among the levels as treated based on the various oils except gross energy, $\mathrm{Mg}, \mathrm{K}, \mathrm{P}, \mathrm{Ca} / \mathrm{P}, \mathrm{Fe} / \mathrm{Pb}$ and $\mathrm{K} / \mathrm{Co}$. Also on pairwise comparison from linear correlation and regression, all these parameters were significantly different at $r=0.01$ between the unprocessed and fried plantain samples: proximate, percentage energy distribution, mineral and mineral ratios. Generally, the first (day) frying showed fairly high nutrient concentration than the first and second re-use oils products. Therefore, for optimum nutrient preservation from fried plantain chips re-use of oil for
\end{abstract}


frying should be sparingly allowed. However, olive showed highest level of nutrients in terms of proximate and mineral compositions.

\section{Keywords}

Vegetable Oils, Plantain Chips, Proximate, Minerals, Ratios, Safety Index

\section{Introduction}

According to FAO [1], plantain (Musa parasidiaca L) is described as a tropical fruit forming a major staple food crop in Central and West Africa. In Nigeria, the annual production recorded about 2.11 million metric tons [1]. It is generally called "Ogede" in Yoruba language [2], "Ayaba" in Hausa language [3]. Its consumption by the household in Nigeria entails different variation but the most preferred plantain varieties are the false horn type locally called "Agbagba" [4]. In the south-western part of Nigeria, plantains are eaten in various forms such as boiled, fried (in the forms of chips, "Dodo", etc.), roasted (Booli), pounded (after being cooked and may be eaten with any desired soup) and dried powdered (usually called "Elubo ogede" employed in the preparation of "Amala"). All these forms involved various degrees of ripening. Loss of vitamins and other nutrients has been reported as a result of cooking or processing techniques [5]. Steaming, boiling, roasting and frying are the most commonly used processing methods [3].

Various authors have reported the use of vegetable oils in the processing of plantain into chips; oils such as palm, refined palm olein, soya oil, olive oil [3], canola and soya oil [6]. The attributes (nutrients composition, taste, etc.) of the finished (fried) products are usually affected by the type of oil, oil temperature and time (length) of frying [6]. According to Mba et al. [7], the ability of fried foods to trap and uptake oils may result from low oil temperature. It has also been observed that cooking of food could result in the improvement of sensory qualities, antioxidant destruction of toxins and plant secondary metabolites, digestibility and nutrient (minerals) bioavailability, although during this process, loss of some micronutrients (vitamins and minerals) has been reported [3] [8] [9].

Adeyeye et al. [3] observed the reduction in the levels of antioxidant activities of plantain chips obtained from use and reuse of selected vegetable oils. This observation attests to the fact that re-use of oils has undesirable effects on fried products which in turn may pose threats to consumer's health. Moreover, plantain chips have become a delicacy and ready to eat snacks among the populace and nutrient indices cannot be ascertained due to the various processes and oil engaged in the process by the consumers. In view of the favourable disposition of the people towards the consumption of plantain chips and their health, this work was initiated to evaluate the effects of repeated use of selected vegetable oils on the proximate composition, minerals and mineral safety index of plantain chips. 


\section{Materials and Methods}

\subsection{Sample Collection and Treatments}

A bunch of fresh matured unripe plantain used for this research was purchased from Iworoko market and properly certified in the Plant Science and Biotechnology laboratory of the Ekiti State University, Ado-Ekiti. The vegetable oils (refined palm olein, olive and coconut oil) used for the frying were purchased from reputable dealers in Ado-Ekiti, Ekiti State.

The plantain chips and its flours were prepared following the method described by Adeyeye et al. [3].

\subsection{Proximate Composition Analysis}

The micro-Kjeldahl method [10] was followed to determine the crude protein. The crude fat was extracted with chloroform/methanol (2:1 v/v) mixture using Soxhlet extraction apparatus. Moisture, ash and crude fibre determination followed AOAC [11] methods whilst carbohydrate was determined by difference. The calorific values in kilo Joule $(\mathrm{kJ})$ were calculated by multiplying the crude fat, protein and carbohydrate by Atwater factors of (kJ) 37, 17 and 17 respectively. Determinations were in duplicate.

\subsection{Mineral Composition Analysis}

The minerals were analysed from the solutions obtained by first dry ashing the samples at $550^{\circ} \mathrm{C}$. The filtered solutions were used to determine $\mathrm{Na}, \mathrm{K}, \mathrm{Mg}, \mathrm{Ca}$, $\mathrm{Fe}, \mathrm{Cu}, \mathrm{Co}, \mathrm{Mn}, \mathrm{Zn}, \mathrm{Pb}, \mathrm{Se}, \mathrm{Cd}$ and $\mathrm{Ni}$ by means of atomic absorption spectrophotometer (Buck Scientific Model -200A/210, Norwalk, Connecticut 06855) and phosphorus was determined colorimetrically by Spectronic 20 (Gallenkamp, UK) using the phosphovanado molybdate method [11]. All chemicals used were of British Drug House (BDH, London, UK) analytical grade. The detection limits for the metals in aqueous solutions had been determined previously using the methods of Varian Techtron [12]. The optimal analytical range was $0.1-0.5$ absorbance units with coefficients of variation from $0.9 \%-2.21 \%$.

Some calculations were made from the analytical results:

1) Estimation of percentage energy contribution: The proportions of energy contribution from fat (PEF), protein (PEP) and carbohydrate (PEC) to total energy were calculated for each nutrient type. Values were reported in both $\mathrm{kJ}$ $100 \mathrm{~g}^{-1}$ and percent. Also calculated was the utilization of energy due to protein (UEDP\%) in the samples.

2) Estimation of mineral ratios: Ratios of $\mathrm{Ca} / \mathrm{Mg}, \mathrm{Na} / \mathrm{K}, \mathrm{Ca} / \mathrm{K}, \mathrm{Na} / \mathrm{Mg}$, $\mathrm{Zn} / \mathrm{Cu}, \mathrm{Ca} / \mathrm{P}, \mathrm{Fe} / \mathrm{Cu}, \mathrm{Ca} / \mathrm{Pb}, \mathrm{Fe} / \mathrm{Pb}, \mathrm{Zn} / \mathrm{Cd}, \mathrm{Fe} / \mathrm{Co}, \mathrm{K} / \mathrm{Co}$ and $[\mathrm{K} /(\mathrm{Ca}+\mathrm{Mg})]$ were all calculated [13] [14] [15].

3) Minerals safety index: The minerals safety index (MSI) was calculated [13] for minerals that have relevant standards for such determination. For the present work, MSI for these minerals were calculated: $\mathrm{Fe}, \mathrm{Ca}, \mathrm{P}, \mathrm{Mg}, \mathrm{Zn}, \mathrm{Cu}$, Se and $\mathrm{Na}$ using the formula: 


$$
\text { Calculated MSI }=\frac{\text { MSI X research data result }}{\text { RAI }}
$$

where MSI = mineral safety index from the Table (standard); RAI = recommended adult intake.

\subsection{Statistical Evaluation}

Data results in Tables 1-3 were subjected to statistical analyses of Chi-square correlation coefficients $\left(r_{x y}\right)$, regression coefficients $\left(R_{x y}\right)$, coefficients of alienation $\left(C_{A}\right)$, index of forecasting efficiency (IFE), coefficient of determination or variance $\left(r_{x y}^{2}\right)$ as the case may be. Other calculations made were grand mean, standard deviation (SD) and coefficients or variation (CV\%). The $r_{x y}$ values were converted to critical Table values to find out if significant differences existed among sample results at $r=0.01$ [16]. The $\mathrm{C}_{\mathrm{A}}$ and IFE values were obtained using the following formulae [17]:

$$
\begin{gathered}
C_{A}=\sqrt{1-\left(r_{x y}\right)^{2}} \\
F E=\left(1-C_{A}\right) \times 100
\end{gathered}
$$

\section{Results and Discussion}

The proximate composition and various percentage energy contributions (from fat, protein and carbohydrates) of raw and fried plantains using selected vegetable oils: olive, refined palm olein and coconut are depicted in Table 1 . Moisture content (\%) for UPC (9.00), $\mathrm{OPC}_{1,2,3}\left(8.20\right.$ - 9.70, CV\%: 6.98), $\mathrm{VPC}_{1,2,3}(10.2$ 12.3, CV\%: 7.96) $\mathrm{CPC}_{1,2,3}(9.00$ - 11.4, CV\%: 9.61) and general CV\% (for UPC, $\mathrm{OPC}$ and CPC) 11.7; Crude protein (\%) for UPC (8.00), $\mathrm{OPC}_{1,2,3}(8.15-8.25$, CV\%: 0.5), $\mathrm{VPC}_{1,2,3}\left(7.5\right.$ - 8.10, CV\%: 3.18), $\mathrm{CPC}_{1,2,3}(8.00$ - 8.60, CV\%: 3.19) and general CV\% (for UPC, OPC and CPC) 3.28; Crude fat (\%) for UPC (12.2), $\mathrm{OPC}_{1,2,3}\left(11.4\right.$ - 12.9, CV\%: 5.04), $\mathrm{VPC}_{1,2,3}$ (8.20 - 13.5; CV\%: 20.8), $\mathrm{CPC}_{1,2,3}(7.40$ - 12.2, CV\%: 20. 4) and general CV\% (for UPC, VPC and CPC), 18.00; Crude fibre (\%) for UPC (3.61), $\mathrm{OPC}_{1,2,3}\left(3.62\right.$ - 3.71, CV\%: 1.06), $\mathrm{VPC}_{1,2,3}(3.50$ - 3.90, CV\%: 4.41), $\mathrm{CPC}_{1,2,3}$ (3.61 - 4.90, CV\%: 13.5) and overall CV\% (for UPC, VPC and CPC), 10.0; ash content (\%) for UPC (2.90), $\mathrm{OPC}_{1,2,3}(3.13-3.24, \mathrm{CV} \%$ : 1.51) $\mathrm{VPC}_{1,2,3}(2.80, \mathrm{CV} \%: 8.52), \mathrm{CPC}_{1,2,3}(2.90$ - 3.80: 11.0) and general CV\% (for UPC, VPC and CPC), 8.83; CHO (\%) for UPC (64.3), $\mathrm{OPC}_{1,2,3}$ (63.4 - 65.4, CV\%: 1.28), $\mathrm{VPC}_{1,2,3}\left(62.3\right.$ - 70.8, CV\%: 5.29), $\mathrm{CPC}_{1,2,3}$ (63.9 - 64.8, CV\%: 0.572); PEC(\%) for UPC, OPC, VPC and $\mathrm{CPC}_{1,2,3}(62.3$ - 64.8, CV\%, 4.67), PEF (\%) for UPC, OPC, VPC and $\mathrm{CPC}_{1,2,3}(18.6$ - 30.2, CV\%, 14.4), PEP(\%) for UPC, $\mathrm{OPC}_{1,2,3}, \mathrm{VPC}_{1,2,3}$ and $\mathrm{CPC}_{1,2,3}(7.30$ - 9.66, CV\%, 6.71) UEDP(\%) (4.49 - 5.80, $\mathrm{CV} \%, 6.71)$ and the gross energy $(\mathrm{kJ} / 100 \mathrm{~g})(1514-1717, \mathrm{CV} \%, 4.15)$.

The moisture content is very important in life maintenance and its determination is essential for the determination of how the food will be processed and its shelf life. According to Davey [18], moisture contents have been used as a measure of stability and susceptibility to microbial attack. Considering the three oils 
Table 1. Proximate composition and various percentage energy contributions (from fat, protein and carbohydrates) of raw and fried plantains (in selected vegetable oils: olive, refined palm olein and coconut).

\begin{tabular}{|c|c|c|c|c|c|c|c|c|c|c|c|}
\hline Parameters & $\begin{array}{c}\text { Moisture } \\
(\%)\end{array}$ & $\begin{array}{c}\text { Crude } \\
\text { protein (\%) }\end{array}$ & $\begin{array}{c}\text { Crude fat } \\
(\%)\end{array}$ & $\begin{array}{c}\text { Crude } \\
\text { fibre (\%) }\end{array}$ & Ash (\%) & $\begin{array}{l}\mathrm{CHO} \\
(\%)\end{array}$ & PEC \% & $\begin{array}{c}\text { PEF } \\
\%\end{array}$ & $\begin{array}{c}\text { PEP } \\
\%\end{array}$ & $\begin{array}{c}\text { UEDP } \\
\%\end{array}$ & $\begin{array}{c}\text { Gross energy } \\
(\mathrm{kJ} / 100 \mathrm{~g})\end{array}$ \\
\hline UPC & 9.00 & 8.00 & 12.2 & 3.61 & 2.90 & 64.3 & 64.6 & 27.4 & 8.03 & 4.82 & 1693 \\
\hline $\mathrm{OPC}_{1}$ & 9.29 & 8.2 & 12.2 & 3.64 & 3.15 & 63.5 & 64.2 & 27.5 & 8.28 & 4.97 & 1683 \\
\hline $\mathrm{OPC}_{2}$ & 9.70 & 8.25 & 11.4 & 3.71 & 3.24 & 63.7 & 65.4 & 26.2 & 8.47 & 5.08 & 1656 \\
\hline $\mathrm{OPC}_{3}$ & 8.20 & 8.15 & 12.9 & 3.62 & 3.13 & 64.0 & 63.4 & 28.6 & 8.07 & 4.84 & 1717 \\
\hline Mean $^{\mathrm{a}}$ & 9.06 & 8.20 & 12.2 & 3.66 & 3.17 & 63.7 & 64.3 & 27.4 & 8.27 & 4.96 & 1685 \\
\hline $\mathrm{SD}^{\mathrm{a}}$ & 0.633 & 0.041 & 0.613 & 0.039 & 0.048 & 0.205 & 0.822 & 0.981 & 0.163 & 0.098 & 25.0 \\
\hline $\mathrm{CV} \%^{\mathrm{a}}$ & 6.98 & 0.500 & 5.04 & 1.06 & 1.51 & 0.320 & 1.28 & 3.58 & 1.97 & 1.98 & 1.48 \\
\hline $\mathrm{VPC}_{1}$ & 10.2 & 7.50 & 13.5 & 3.50 & 2.80 & 62.5 & 62.3 & 30.2 & 7.48 & 4.49 & 1704 \\
\hline $\mathrm{VPC}_{2}$ & 12.3 & 8.10 & 8.20 & 3.90 & 3.45 & 64.1 & 70.8 & 20.2 & 8.95 & 5.37 & 1539 \\
\hline $\mathrm{VPC}_{3}$ & 10.8 & 7.90 & 10.0 & 3.72 & 3.10 & 64.5 & 68.1 & 23.6 & 8.34 & 5.00 & 1611 \\
\hline Mean $^{\mathrm{b}}$ & 11.1 & 7.83 & 10.6 & 3.71 & 3.12 & 63.7 & 67.1 & 24.7 & 8.26 & 4.95 & 1618 \\
\hline $\mathrm{SD}^{\mathrm{b}}$ & 0.883 & 0.249 & 2.20 & 0.164 & 0.266 & 0.864 & 3.55 & 4.15 & 0.603 & 0.361 & 67.5 \\
\hline $\mathrm{CV} \%^{\mathrm{b}}$ & 7.96 & 3.18 & 20.8 & 4.41 & 8.52 & 1.36 & 5.29 & 16.8 & 7.30 & 7.28 & 4.17 \\
\hline $\mathrm{CPC}_{1}$ & 11.4 & 8.60 & 7.40 & 4.90 & 3.80 & 63.9 & 71.8 & 18.6 & 9.66 & 5.8 & 1514 \\
\hline $\mathrm{CPC}_{2}$ & 10.5 & 8.10 & 9.40 & 3.86 & 3.30 & 64.8 & 69.0 & 22.4 & 8.62 & 5.17 & 1597 \\
\hline $\mathrm{CPC}_{3}$ & 9.00 & 8.00 & 12.2 & 3.61 & 2.90 & 64.3 & 64.6 & 27.4 & 8.04 & 4.82 & 1693 \\
\hline Mean $^{c}$ & 10.3 & 8.23 & 9.67 & 4.12 & 3.33 & 64.3 & 68.5 & 22.8 & 8.80 & 5.30 & 1601 \\
\hline $\mathrm{SD}^{\mathrm{c}}$ & 0.990 & 0.262 & 1.97 & 0.559 & 0.368 & 0.368 & 2.96 & 3.60 & 0.670 & 0.405 & 73.1 \\
\hline $\mathrm{CV}^{\mathrm{c}}$ & 9.61 & 3.19 & 20.4 & 13.5 & 11.0 & 0.572 & 4.33 & 15.8 & 7.64 & 7.70 & 4.57 \\
\hline Mean $^{g}$ & 10.0 & 8.08 & 10.9 & 3.81 & 3.18 & 64 & 66.4 & 25.2 & 8.39 & 5.04 & 1641 \\
\hline $\mathrm{SD}^{\mathrm{g}}$ & 1.17 & 0.265 & 1.97 & 0.382 & 0.28 & 0.616 & 3.1 & 3.62 & 0.563 & 0.338 & 68.1 \\
\hline $\mathrm{CV} \%^{\mathrm{g}}$ & 11.7 & 3.28 & 18.0 & 10.0 & 8.83 & 0.963 & 4.67 & 14.37 & 6.71 & 6.71 & 4.15 \\
\hline$x^{2}$ & 1.37 & 0.087 & 3.55 & 0.383 & 0.247 & 0.059 & 1.45 & 5.20 & 0.377 & 0.226 & 28.3 \\
\hline Remark & NS & NS & NS & NS & NS & NS & NS & NS & NS & NS & S \\
\hline
\end{tabular}

$\mathrm{U}=$ unprocessed, $\mathrm{O}=$ olive oil, $\mathrm{V}=$ refined palm olein, $\mathrm{C}=$ coconut oil, $\mathrm{PC}=$ plantain chips, 1 = product of first frying (first day), $2=$ product of second frying (first re-use of oil), $3=$ product of third frying (second re-use of oil), $\mathrm{SD}=$ standard deviation, $\mathrm{CV}=$ coefficient of variation, $\chi^{2}=\mathrm{Chi}-\mathrm{square}$ at $n-1$, $\mathrm{r}={ }_{0.05}, \mathrm{~S}=$ significantly different, NS = not significantly different, ${ }^{\mathrm{a}}=$ mean, $\mathrm{SD}, \mathrm{CV} \%$ of $\mathrm{OPC}_{1,2,3}{ }^{\mathrm{b}}=$ mean, $\mathrm{SD}, \mathrm{CV} \%$ of $\mathrm{VPC}_{1,2,3} ;{ }^{\mathrm{c}}=\mathrm{mean} \mathrm{SD}, \mathrm{CV} \%$ of $\mathrm{CPC}_{1,2,3} ;{ }^{\mathrm{g}}=$ general mean, $\mathrm{SD}, \mathrm{CV} \%$ of UPC, $\mathrm{OPC}_{1,2,3}, \mathrm{VPC}_{1,2,3}$ and $\mathrm{CPC}_{1,2,3}$.

used, lowest moisture level was observed as follows: $\mathrm{OPC}_{3}, 8.20 \%$; $\mathrm{VPC}_{1}, 10.2 \%$; $\mathrm{CPC}_{3}, 9.00 \%$. Generally, the levels of moisture observed in the chips from the oils used were low to allow long shelf life and the fluctuations observed in the trend could be as result of the differences in the heating values of the oils [6] and frying oil type. However, the observed values were comparably lower than values reported for chips fried with carola oil, soya oil (12\% - 14\%) [6] and values recorded for unripe, overripe and ripe plantain peels (13.28\% - 20.38\%) [4].

The levels of crude proteins both in the raw and fried samples among the selected oils were generally low. The values however, were comparably higher than 
values reported for unripe, ripe and over ripe plantain peels (4.21\% - 7.89\%) [4], five species of traditional vegetables (Lycopesicon esculentum, Abelmoschus esculentus, Daucus carola, Brassica oleracea and Spinacia oleracea) consumed in Nigeria $(0.86 \%-2.23 \%)$ [19] but lower than those values reported for the garden egg leaf, African spinach and Bush okro (15.5\% - 32.1\%) [20]. The levels of crude protein contents varied among the samples following the pattern shown below: $\mathrm{UPC}<\mathrm{OPC}_{1}<\mathrm{OPC}_{2}>\mathrm{OPC}_{3} ; \mathrm{UPC}>\mathrm{VPC}_{1}<\mathrm{VPC}_{2}>\mathrm{VPC}_{3} ; \mathrm{UPC}<$ $\mathrm{CPC}_{1}>\mathrm{CPC}_{2}>\mathrm{CPC}_{3}$. Among the samples from the various oils and length of frying, it was shown that the third day frying (second re-use of oil) had the least value in terms of protein contents this may be due to the effects of heating which causes protein to denature or oxidize.

The crude fat content in both the raw and fried chips for all the oils were generally fairly low perhaps due to low oil uptake during the frying process [7]. The observed values on the other hand were generally higher than what was reported for some vegetables consumed in Nigeria [19] [20] and peels of plantains [4]. However, when compared to some animal samples, it was observed that the lipid levels of the raw and plantain chips samples were favourably comparable, for instance, male and female Callianassa turnerana (12.3\% - 13.0\%) [21], and higher in some instances (flesh of male and female Neopetrolisthes maculatus) $(4.05 \%$ 4.45\%) [22] and Callnectes pallidus and Cardisoma armatum (1.65 - 2.09\%) [23]. The trends among the oils and frying process were as follows: UPC $\equiv \mathrm{OPC}_{1}>$ $\mathrm{OPC}_{2}<\mathrm{OPC}_{3}$; UPC $<\mathrm{VPC}_{1}>\mathrm{VPC}_{2}<\mathrm{VPC}_{3}$ and $\mathrm{UPC}>\mathrm{CPC}_{1}<\mathrm{CPC}_{2}<\mathrm{CPC}_{3}$.

The levels of crude fibre in the present study were generally low. However, the values fell within those reported for selected vegetables consumed in Nigeria $(2.75 \%-6.36 \%)$ [19] [20]. Also in accordance with the report of Akindahunsi and Salawu [24] and Anita et al. [25] for P. guineensis and Corchorus olitorius samples respectively. Fibre is essential for the intestinal health and in the prevention of excess cholesterol absorption. Dietary fibres, mainly cellulose and hemicelluloses add bulk to the diet, ease fecal elimination and prevent adsorption of excess starchy diets which protects metabolic conditions against hyper cholesterolemia, diabetes mellitus and other related health conditions [20].

The ash content is the indicative of the mineral composition of any food sample. According to Adeyeye and Adubiaro [22] moderate level of protein would result into moderate level of crude fat, total ash and low level of carbohydrate. The ash contents in the samples (raw and fried plantains) showed that the samples would contain moderate levels of minerals. Looking at the results, the low values of coefficient of variation percent showed that they were very closely varied. The variation of the results among the different oils used were as follows $\mathrm{UPC}<\mathrm{OPC}_{1}<\mathrm{OPC}_{2}>\mathrm{OPC}_{3}, \mathrm{UPC}>\mathrm{VPC}_{1}<\mathrm{VPC}_{2}>\mathrm{VPC}_{3}$ and $\mathrm{UPC}<\mathrm{CPC}_{1}<$ $\mathrm{CPC}_{2}>\mathrm{VPC}_{3}$. The carbohydrate levels in the present report were moderately high and were in agreement with values reported for unripe, ripe and over ripe plantain peels [4] but comparably higher than those reported for plantain chips fried with canola and soya oils [6].

As seen in Table 1, the various energy contribution as proportion of the total 
energy from the raw and fried plantain chips in the various oils had a general trend of PEC\% > PEF\% > PEP\%. Except in $\mathrm{VPC}_{1}$ with a value of $30.2 \%$ for PEF\% the rest of the samples fell slightly below the recommended level of 30\% [26] and $35 \%$ [27] for total fat intake (assuming it serves as the only source of fat in the diet), such is good for people aspiring to adopt the guidelines for a healthy diet [22]. The utilizable energy due to protein (UEDP \%) had a value range of 4.82 5.80 (assuming $60 \%$ of protein energy utilization). It is interesting to note that these values were slightly fell below the recommended safe level of $8 \%$ for an adult who requires about $55 \mathrm{~g}$ protein per day with $60 \%$ utilization.

The energy values from the samples were moderately high and favourably comparable to those samples from animal source (flesh of male and female $N$. maculatus) [22] and comparatively higher than those reported for selected vegetables consumed in Nigeria [19]. The lowest energy was observed in the samples obtained from the second day frying/first re-use of coconut oil $\left(\mathrm{CPC}_{1}\right)(1514$ $\mathrm{kJ} / 100 \mathrm{~g}$ ) with the highest being $\mathrm{CPC}_{3}$ (second re-use of the oil), for the olive oil (OPC), the highest was during the first day frying $(1717 \mathrm{~kJ} / 100 \mathrm{~g})$ and for the refined palm olein (VPC), the highest energy was observed in the chips obtained from the first day frying $(1704 \mathrm{~kJ} / 100 \mathrm{~g})$.

Table 2 gives the mineral composition of raw and fried plantains (in selected vegetable oils: olive, refined palm olein and coconut). The results $(\mathrm{mg} / 100 \mathrm{~g})$ for UPC, $\mathrm{OPC}_{1,2,3}, \mathrm{VPC}_{1,2,3}$ and $\mathrm{CPC}_{1,2,3}$ ranged as follows among the oils used respectively: $\mathrm{Fe}$ (3.22, 2.52 - 2.61; 2.49 - 02.82 and $2.74-3.06), \mathrm{Cu}(1.47,1.15$ $1.19 ; 1.03-1.29$ and $1.07-1.40)$, Co $(0.0014,0.001-0.0011 ; 0.001-0.0012$ and 0.001 - 0.0013), $\mathrm{Mn}(2.49,1.95-2.02 ; 1.75-2.18$ and $1.81-2.37), \mathrm{Pb}(0.0006$, $0.0005-0.0006 ; 0.0004-0.0005$ and $0.0004-0.0006), \mathrm{Zn}(3.44,2.69-2.79 ; 2.41-$ 3.01 and 2.49 - 3.27), Ca (116, 91.0 - 94.2; 81.4 - 102 and 84.3 - 110), $\mathrm{Mg}(182$, 143 - 148; 128 - 159 and 132 - 173), K (484, 379 - 392; 339 - 424 and $351-480)$, $\mathrm{Na}(48.3,37.8-42.3$ and $35.0-45.9)$, Se (0.0016, $0.0012-0.0013 ; 0.0011-0.0014$ and $0.0012-0.0015), \mathrm{Cd}(0.0005,0.0041-0.00042 ; 0.00036-0.00046$ and $0.00038-$ $0.00049), \mathrm{Ni}(0.0363,0.0283-0.0293 ; 0.0253-0.0317$ and $0.0282-0.0344)$ and $\mathrm{P}$ $(238,186$ - 193; 167 - 208 and 173 - 226).

The following minerals had low concentrations in all the samples and at various levels of frying processes: $\mathrm{Fe}, \mathrm{Cu}, \mathrm{Co}, \mathrm{Pb}, \mathrm{Se}, \mathrm{Cd}, \mathrm{Ni}$, and $\mathrm{Mn}$. Potassium had the highest level among all the samples, followed by phosphorus, magnesium, then calcium and sodium. According to Baiyeri et al. [28], light green stage of plantain had a relatively high mineral constituent of $\mathrm{K}, \mathrm{P}, \mathrm{Mg}$ and $\mathrm{Ca}$. The variations observed among the various mineral constituents of the samples (for raw and fried products) on the basis of oils used, the mineral levels did not change significantly.

Minerals are considered to be essential in human nutrition and generally, minerals from plant sources are less bioavailable than those from animal sources [29]. The level of minerals recorded in present samples were comparably close to those of unripe, ripe and over ripe plantain peels [4], Aneilema aequinoctiale, 
Table 2. Mineral composition ( $\mathrm{mg} / 100 \mathrm{~g}$ ) of raw and fried plantains (in selected vegetable oils: olive, refined palm olein and coconut).

\begin{tabular}{|c|c|c|c|c|c|c|c|c|c|c|c|c|c|c|}
\hline Samples & $\mathrm{Fe}$ & $\mathrm{Cu}$ & Co & $\mathrm{Mn}$ & $\mathrm{Pb}$ & $\mathrm{Zn}$ & $\mathrm{Ca}$ & $\mathrm{Mg}$ & $\mathrm{K}$ & $\mathrm{Na}$ & $\mathrm{Se}$ & $\mathrm{Cd}$ & $\mathrm{Ni}$ & $\mathrm{P}$ \\
\hline UPC & 3.22 & 1.47 & 0.0014 & 2.49 & 0.0006 & 3.44 & 116 & 182 & 484 & 48.3 & 0.0016 & 0.0005 & 0.0363 & 238 \\
\hline $\mathrm{OPC}_{1}$ & 2.53 & 1.16 & 0.0011 & 1.97 & 0.0005 & 2.71 & 91.6 & 143 & 381 & 38 & 0.0013 & 0.00041 & 0.0285 & 188 \\
\hline $\mathrm{OPC}_{2}$ & 2.61 & 1.19 & 0.0011 & 2.02 & 0.0005 & 2.79 & 94.2 & 148 & 392 & 39.1 & 0.0013 & 0.00042 & 0.0293 & 193 \\
\hline $\mathrm{OPC}_{3}$ & 2.52 & 1.15 & 0.0011 & 1.95 & 0.0005 & 2.69 & 91 & 143 & 379 & 37.8 & 0.0012 & 0.00041 & 0.0283 & 186 \\
\hline Mean $^{\mathrm{a}}$ & 2.55 & 1.17 & 0.0011 & 1.98 & 0.0005 & 2.73 & 92.3 & 145 & 384 & 38.3 & 0.0013 & 0.0004 & 0.0287 & 189 \\
\hline $\mathrm{SD}^{\mathrm{a}}$ & 0.040 & 0.017 & 0.00 & 0.029 & 0.00 & 0.043 & 1.39 & 2.36 & 5.72 & 0.572 & $4.71 \mathrm{e}-5$ & $4.71 \mathrm{e}-6$ & 0.0004 & 2.94 \\
\hline $\mathrm{CV} \%^{\mathrm{a}}$ & 1.58 & 1.46 & 0.00 & 1.49 & 0.00 & 1.58 & 1.51 & 1.63 & 1.49 & 1.49 & 3.72 & 1.14 & 1.51 & 1.56 \\
\hline $\mathrm{VPC}_{1}$ & 2.25 & 1.03 & 0.001 & 1.75 & 0.0004 & 2.41 & 81.4 & 128 & 339 & 33.8 & 0.0011 & 0.00036 & 0.0253 & 167 \\
\hline $\mathrm{VPC}_{2}$ & 2.82 & 1.29 & 0.0012 & 2.18 & 0.0005 & 3.01 & 102 & 159 & 424 & 42.3 & 0.0014 & 0.00046 & 0.0317 & 208 \\
\hline $\mathrm{VPC}_{3}$ & 2.49 & 1.14 & 0.0011 & 1.93 & 0.0005 & 2.66 & 90.1 & 141 & 375 & 37.4 & 0.0012 & 0.0004 & 0.0281 & 185 \\
\hline Mean $^{\mathrm{b}}$ & 2.52 & 1.15 & 0.0011 & 1.95 & 0.0005 & 2.69 & 91.2 & 143 & 379 & 37.8 & 0.0012 & 0.00041 & 0.028 & 187 \\
\hline $\mathrm{SD}^{\mathrm{b}}$ & 0.234 & 0.107 & $8.16 \mathrm{e}-5$ & 0.176 & $4.7 \mathrm{e}-5$ & 0.246 & 8.44 & 12.7 & 34.8 & 3.48 & 0.00012 & 0.00004 & 0.003 & 16.8 \\
\hline $\mathrm{CV} \%^{\mathrm{b}}$ & 9.272 & 9.24 & 7.42 & 9.03 & 10.1 & 9.14 & 9.26 & 8.91 & 9.18 & 9.21 & 10.1 & 10.11 & 9.23 & 8.99 \\
\hline $\mathrm{CPC}_{1}$ & 3.06 & 1.4 & 0.0013 & 2.37 & 0.0006 & 3.27 & 110 & 173 & 480 & 45.9 & 0.0015 & 0.00049 & 0.0344 & 226 \\
\hline $\mathrm{CPC}_{2}$ & 2.74 & 1.25 & 0.0012 & 2.06 & 0.0005 & 2.84 & 96 & 150 & 400 & 39.8 & 0.0013 & 0.00043 & 0.0299 & 196 \\
\hline $\mathrm{CPC}_{3}$ & 2.34 & 1.07 & 0.001 & 1.81 & 0.0004 & 2.49 & 84.3 & 132 & 351 & 35 & 0.0012 & 0.00038 & 0.0282 & 173 \\
\hline Mean $^{c}$ & 2.71 & 1.24 & 0.0012 & 2.08 & 0.0005 & 2.87 & 96.8 & 152 & 410 & 40.2 & 0.0013 & 0.00043 & 0.031 & 198 \\
\hline $\mathrm{SD}^{\mathrm{c}}$ & 0.295 & 0.135 & 0.00012 & 0.229 & $8.2 \mathrm{e}-5$ & 0.319 & 10.5 & 16.8 & 53.2 & 4.46 & 0.00012 & $4.5 e-5$ & 0.0026 & 21.7 \\
\hline $\mathrm{CV} \%{ }^{\mathrm{c}}$ & 10.9 & 10.9 & 10.7 & 11.0 & 16.3 & 11.1 & 10.9 & 11.1 & 13.0 & 11.1 & 9.35 & 10.4 & 8.48 & 10.9 \\
\hline Mean & 2.66 & 1.22 & 0.0012 & 2.05 & 0.0005 & 2.83 & 95.7 & 150 & 401 & 39.7 & 0.0013 & 0.00043 & 0.03 & 196 \\
\hline $\mathrm{SD}$ & 0.288 & 0.133 & 0.0001 & 0.222 & 0.0001 & 0.308 & 10.4 & 16.3 & 46.5 & 4.33 & 0.0001 & 0.00004 & 0.003 & 21.3 \\
\hline CV\% & 10.9 & 10.9 & 10.5 & 10.8 & 12.6 & 10.9 & 10.9 & 10.9 & 11.6 & 10.9 & 11.1 & 10.1 & 10.4 & 10.9 \\
\hline$x^{2}$ & 0.313 & 0.145 & 0.0001 & 0.239 & 0.0001 & 0.335 & 11.3 & 17.8 & 54 & 4.71 & 0.0002 & 0.00004 & 0.003 & 23.2 \\
\hline Remark & NS & NS & NS & NS & NS & NS & NS & $S$ & $S$ & NS & NS & NS & NS & $S$ \\
\hline
\end{tabular}

$\mathrm{NS}=$ not significantly different at $\alpha={ }_{0.05}, \mathrm{~S}=$ significantly different at $\alpha={ }_{0.05}, \chi^{2}=$ Chi-square, ${ }^{\mathrm{a}} \mathrm{mean}, \mathrm{SD}, \mathrm{CV} \%$ of OPC ${ }_{1,2,3} ;{ }^{\mathrm{b}}=\mathrm{mean} \mathrm{SD}, \mathrm{CV} \%$ of $\mathrm{VPC}{ }_{1,2,3} ;{ }^{\mathrm{c}}$ $=$ mean, $\mathrm{SD}, \mathrm{CV} \%$ of $\mathrm{CPC}_{1,2,3} ;{ }^{\mathrm{g}}=$ general mean, $\mathrm{SD}, \mathrm{CV} \%$ of UPC, $\mathrm{OPC}_{1,2,3}, \mathrm{VPC}_{1,2,3}$ and $\mathrm{CPC}_{1,2,3}$.

some vegetables consumed in Nigeria [19] [20]. Calcium is one of the most essential macro mineral required by the body for strong teeth and bone and its deficiency is more prevalent than any other mineral. Calcium, phosphorus, and vitamin D help to reduce/eradicate rickets in children and osteomalacia as well as osteoporosis among older people [30]. Magnesium function as an activator of ATPs requiring enzymes such as hexokinase, phosphatase, alkaline, fructokinase and ademylcyclase. It plays a vital role in the structure and the function of the human body such as the skeletons and muscle [20]. The adult humans require about $25 \mathrm{mg}$ of $\mathrm{Mg}$ for normal physiological functions; hence the levels recorded in the present study would meet the requirement safely.

Potassium levels in the present samples were comparable to those observed in 
bush mallow, garden egg leaf, African spinach and Bush okro [20] and values reported by Javed [31] in some selected vegetables grown in Pakistan. Potassium is an intercellular salt that can combine with sodium to influence osmotic pressure and contribute to normal $\mathrm{pH}$ equilibrium in the body [30]. It is interesting to note that the levels of $\mathrm{Na}$ in all the samples were generally fairly low. Its absorption is considered an important factor in the etiology of hypertension hence, it's fairly low availability in these samples can lower the incidence of hypertension.

Zinc is involved in the normal functioning of immune system and is associated with protein metabolism [32]. Hence, the levels recorded in the present samples would contribute positively to the functioning of immune system and protein metabolism of the consumers. Although the levels of iron were low in the present study, however, they are comparably higher than the values recorded for unripe, ripe and over ripe plantain peels [4]. Iron is essential trace element for haemoglobin formation, normal functioning of central nervous system and in the oxidation of carbohydrate and fats [33].

Of note, the highest concentration of minerals in these samples are potassium, magnesium, calcium and phosphorus and the result further indicate that these samples (irrespective of the oils used) can contribute significantly to the mineral nutrition of the consumers.

Computed mineral ratios were depicted in Table 3. Watts [14], stressed the fact that mineral ratios were considered more important than individual mineral contents. Similar idea was supported by Adeyeye and Adubiaro [22], that the determination of nutritional interrelationships entails much more than the knowledge of the mineral level alone. Excess intakes, deficiency and aberrations arising from consumption of a food with respect to mineral elements can only be determined from their ratios which stemmed out of their synergistic roles in nutrition.

Essential ratios calculated included $\mathrm{Ca} / \mathrm{P}, \mathrm{Na} / \mathrm{K}, \mathrm{Ca} / \mathrm{K}, \mathrm{Zn} / \mathrm{Cu}, \mathrm{Ca} / \mathrm{Mg}, \mathrm{Na} / \mathrm{Mg}$ and $\mathrm{Fe} / \mathrm{Cu}$. The afore-listed ratios unveiled not only the important balance between the elements involved but they also provide information regarding the many possible factors that may be represented by alteration of their synergistic relationship which include disease states, physiological and developmental factors, diets and drug interactions and their effects [14].

In animals, a $\mathrm{Ca} / \mathrm{P}$ ratio above 2.0 helps to increase the absorption of calcium in the small intestine. In other words, food is regarded "good" if the ratio $\mathrm{Ca} / \mathrm{P}$ is greater than 1.0 and "poor" if less than 0.50 [34]. In the present study the level of $\mathrm{Ca} / \mathrm{P}$ were as follow in the samples of plantain chips obtained from all the oils and the various processes of frying (UPC, $\mathrm{OPC}_{1,2,3} \mathrm{VPC}_{1,2,3}$ and $\mathrm{CPC}_{1,2,3}$ ): 0.487 0.490 . For sodium/potassium $(\mathrm{Na} / \mathrm{K})$, ideally there should be a 2.4: 1 ratio of sodium relative to potassium with a range of 1.4 to 3.4 being acceptable. The sample results gave values range of $0.0096-0.100$ for $\mathrm{Na} / \mathrm{K}$ which fell greatly below the ideal range. It is worthy of note that all the essential ratios have their values in the results being less than the ideal range and also not falling within the acceptable 
Table 3. Computed mineral ratios of raw and fried plantains (in selected vegetable oils: olive, refined palm olein and coconut).

\begin{tabular}{|c|c|c|c|c|c|c|c|c|c|c|c|c|}
\hline Samples & $\mathrm{Ca} / \mathrm{Mg}$ & $\mathrm{Ca} / \mathrm{P}$ & $\mathrm{Na} / \mathrm{K}$ & {$[\mathrm{K} /(\mathrm{Ca}+\mathrm{Mg})]^{*}$} & $\mathrm{Na} / \mathrm{Mg}$ & $\mathrm{Zn} / \mathrm{Cu}$ & $\mathrm{Fe} / \mathrm{Cu}$ & $\mathrm{Ca} / \mathrm{Pb}$ & $\mathrm{Fe} / \mathrm{Pb}$ & $\mathrm{Zn} / \mathrm{Cd}$ & $\mathrm{Fe} / \mathrm{Co}$ & $\mathrm{K} / \mathrm{Co}$ \\
\hline UPC & 0.638 & 0.487 & 0.100 & 3.25 & 0.265 & 2.33 & 2.18 & 193,849 & 5364 & 6877 & 2299 & 345,979 \\
\hline $\mathrm{OPC}_{1}$ & 0.638 & 0.487 & 0.100 & 3.25 & 0.265 & 2.33 & 2.18 & 183,180 & 5069 & 6604 & 2304 & 346,767 \\
\hline $\mathrm{OPC}_{2}$ & 0.638 & 0.488 & 0.100 & 3.25 & 0.265 & 2.33 & 2.18 & 188,400 & 5214 & 6631 & 2370 & 356,673 \\
\hline $\mathrm{OPC}_{3}$ & 0.638 & 0.489 & 0.100 & 3.25 & 0.265 & 2.33 & 2.18 & 182,022 & 5037 & 6562 & 2289 & 344,564 \\
\hline Mean $^{\mathrm{a}}$ & 0.638 & 0.488 & 0.100 & 3.25 & 0.265 & 2.33 & 2.18 & 184,534 & 5107 & 6599 & 2321 & 349,335 \\
\hline $\mathrm{SD}^{\mathrm{a}}$ & 0.00 & $2.9 \mathrm{e}-4$ & $1.4 \mathrm{e}-17$ & 0.00 & 0.00 & 0.00 & 0.00 & 2774 & 77.0 & 28.4 & 35.2 & 5266 \\
\hline $\mathrm{CV} \%^{\mathrm{a}}$ & 0.00 & 0.17 & $1.4 \mathrm{e}-14$ & 0.00 & 0.00 & 0.00 & 0.00 & 1.50 & 1.51 & 0.43 & 1.52 & 1.51 \\
\hline $\mathrm{VPC}_{1}$ & 0.638 & 0.487 & 0.100 & 3.25 & 0.265 & 2.33 & 2.18 & 203,539 & 5632 & 6686 & 2253 & 339,062 \\
\hline $\mathrm{VPC}_{2}$ & 0.638 & 0.490 & 0.100 & 3.25 & 0.265 & 2.33 & 2.18 & 203,539 & 5632 & 6540 & 2347 & 353,190 \\
\hline $\mathrm{VPC}_{3}$ & 0.638 & 0.487 & 0.100 & 3.25 & 0.265 & 2.33 & 2.18 & 180,277 & 4989 & 6662 & 2268 & 341,264 \\
\hline Mean $^{\mathrm{b}}$ & 0.638 & 0.488 & 0.100 & 3.25 & 0.265 & 2.33 & 2.18 & 195,785 & 5418 & 6629 & 2289 & 344,505 \\
\hline $\mathrm{SD}^{\mathrm{b}}$ & 0.00 & 0.0015 & $1.4 \mathrm{e}-17$ & 0.00 & 0.00 & 0.00 & 0.00 & 10,966 & 303 & 63.9 & 41.2 & 6206 \\
\hline $\mathrm{CV}^{\mathrm{b}}$ & 0.00 & 0.31 & $1.4 \mathrm{e}-14$ & 0.00 & 0.00 & 0.00 & 0.00 & 5.60 & 5.59 & 0.964 & 1.80 & 1.80 \\
\hline $\mathrm{CPC}_{1}$ & 0.638 & 0.487 & 0.096 & 3.39 & 0.265 & 2.33 & 2.18 & 184,155 & 5096 & 6666 & 2352 & 369,351 \\
\hline $\mathrm{CPC}_{2}$ & 0.638 & 0.490 & 0.100 & 3.25 & 0.265 & 2.26 & 2.18 & 191,908 & 5471 & 6597 & 2280 & 333,007 \\
\hline $\mathrm{CPC}_{3}$ & 0.638 & 0.487 & 0.100 & 3.25 & 0.265 & 2.33 & 2.19 & 210,808 & 5858 & 6560 & 2343 & 351,171 \\
\hline Mean $^{c}$ & 0.638 & 0.488 & 0.099 & 3.30 & 0.265 & 2.31 & 2.18 & 195,624 & 5475 & 6608 & 2325 & 351,176 \\
\hline $\mathrm{SD}^{\mathrm{c}}$ & 0.00 & 0.0013 & 0.002 & 0.066 & 0.00 & 0.033 & 0.0047 & 11,194 & 311 & 43.9 & 32.0 & 14,837 \\
\hline $\mathrm{CV} \%^{\mathrm{c}}$ & 0.00 & 0.27 & 1.91 & 2.00 & 0.00 & 1.43 & 0.216 & 5.72 & 5.68 & 0.665 & 1.38 & 4.23 \\
\hline Mean & 0.638 & 0.488 & 0.099 & 3.26 & 0.265 & 2.33 & 2.18 & 191,441 & 5316 & 6643 & 2311 & 348,382 \\
\hline $\mathrm{SD}$ & 0.638 & 0.001 & 0.093 & 3.48 & 0.265 & 2.32 & 2.17 & 164,773 & 4561 & 7174 & 2395 & 386,438 \\
\hline CV\% & 1.00 & 0.25 & 0.938 & 1.07 & 1.00 & 1.00 & 1.00 & 0.861 & 0.858 & 1.08 & 1.036 & 1.109 \\
\hline$x^{2}$ & 0.00 & 0.02 & 0.0002 & 0.006 & $1.4 \mathrm{e}-8$ & 0.002 & $3.0 \mathrm{e}-5$ & 5316 & 155 & 12.8 & 6.22 & 2687 \\
\hline Remark & NS & NS & NS & NS & NS & NS & NS & $S$ & $S$ & NS & NS & $\mathrm{S}$ \\
\hline $\mathrm{RBI}$ & 7 & 2.6 & 2.4 & 4.0 & 8.0 & 0.90 & 84.0 & 0.9 & 84 & 4.4 & 500 & 440 \\
\hline AIR & $3-11$ & $1.5-3.6$ & $1.4-3.4$ & $2-6$ & $4-12$ & $0.2-1.6$ & $126-168$ & $0.2-1.6$ & $126-168$ & $6.6-8.8$ & $\begin{array}{l}750- \\
1000\end{array}$ & - \\
\hline
\end{tabular}

* = milliequivalent ratio, NS = not significantly different at $\alpha={ }_{0.05}, \mathrm{~S}=$ significantly different at $\alpha={ }_{0.05}, \chi^{2}=\mathrm{Chi}$-square, ${ }^{\mathrm{a}} \mathrm{mean}, \mathrm{SD}, \mathrm{CV} \%$ of OPC $\mathrm{OP}_{1,2,3}{ }^{\mathrm{b}}=$ mean, $\mathrm{SD}, \mathrm{CV} \%$ of $\mathrm{VPC}_{1,2,3} ;{ }^{\mathrm{c}}=$ mean, $\mathrm{SD}, \mathrm{CV} \%$ of $\mathrm{OPC}_{1,2,3} ;{ }^{\mathrm{g}}=$ general mean, SD, CV\% of UPC, $\mathrm{OPC}_{1,2,3}, \mathrm{VPC}_{1,2,3}$ and $\mathrm{CPC} \mathrm{C}_{1,2,3}$, RBI = reference balance (ideal), AIR = acceptable ideal range.

ideal range. Toxic metal ratios in these results were $\mathrm{Fe} / \mathrm{Pb}, \mathrm{Ca} / \mathrm{Pb}, \mathrm{Zn} / \mathrm{Cd}, \mathrm{Fe} / \mathrm{Co}$ and $\mathrm{K} / \mathrm{Co}$. Their values were comparably higher than the reference balance ideal values [22]. Of note in nutrition is the value of $[\mathrm{K} /(\mathrm{Ca}+\mathrm{Mg})]$. The levels in the samples analyzed were all greater than 2.2 which is the reference balance ideal. This implied that the sample would not cause hypomagnesemia in man.

The mineral safety index (MSI) whose standards were available were calculated and shown in Table 4. The MSI standard values (TV of MSI) were all shown in the Table. In other to have a clearer understanding of MSI calculation, 
let us consider an example: Fe as example, we have: the Recommended Adult Intake (RAI) is $15 \mathrm{mg}$ its minimum toxic dose (MTD) is $150 \mathrm{mg}$ or 10 times the recommended daily allowance (RDA) which is equivalent to the MSI of Fe. The same reasoning goes for other minerals. For all the results observed the difference (D) were all positive (calculated MSI < standard MSI) meaning that such mineral would not constitute mineral overload nor become toxic to the consumers.

In Tables 5-7, we have the report of the statistical analysis of the results from Table 1 and Table 2 respectively. In the statistics, these values were high: $r_{x p}$ $r_{x y}^{2}, R_{x y} \mathrm{CV} \%$ and IFE. The regression coefficient $\left(\mathrm{R}_{\mathrm{xy}}\right)$ value was a reflection of

Table 4. Mineral safety index (MSI) of raw and fried plantains (in selected vegetable oils: olive, refined palm olein and coconut).

\begin{tabular}{|c|c|c|c|c|c|c|c|c|c|c|c|c|c|c|c|c|c|c|c|c|c|c|c|c|}
\hline \multirow{2}{*}{ Samples } & \multicolumn{3}{|c|}{$\mathrm{Fe}(\mathrm{RAI}=15)$} & \multicolumn{3}{|c|}{$\mathrm{Cu}(\mathrm{RAI}=33)$} & \multicolumn{3}{|c|}{$\mathrm{Zn}(\mathrm{RAI}=15)$} & \multicolumn{3}{|c|}{$\mathrm{Ca}(\mathrm{RAI}=1200)$} & \multicolumn{3}{|c|}{$\mathrm{Mg}(\mathrm{RAI}=400)$} & \multicolumn{3}{|c|}{$\mathrm{Na}(\mathrm{RAI}=500)$} & \multicolumn{3}{|c|}{$\mathrm{Se}(\mathrm{RAI}=0.07)$} & \multicolumn{3}{|c|}{$\mathrm{P}(\mathrm{RAI}=1200)$} \\
\hline & TV & $\mathrm{CV}$ & $\mathrm{D}$ & TV & $\mathrm{CV}$ & $\mathrm{D}$ & TV & $\mathrm{CV}$ & $\mathrm{D}$ & TV & $\mathrm{CV}$ & $\mathrm{D}$ & TV & $\mathrm{CV}$ & $\mathrm{D}$ & TV & $\mathrm{CV}$ & $\mathrm{D}$ & TV & $\mathrm{CV}$ & $\mathrm{D}$ & TV & $\mathrm{CV}$ & $\mathrm{D}$ \\
\hline OPC1 & 6.7 & 1.13 & 5.57 & 33 & 1.74 & 31.3 & 33 & 5.96 & 27.0 & 10 & 0.763 & 9.24 & 15 & 5.38 & 9.62 & 4.8 & 0.365 & 4.43 & 14 & 0.252 & 13.7 & 10 & 1.56 & 8.44 \\
\hline OPC2 & 6.7 & 1.16 & 5.54 & 33 & 1.79 & 31.2 & 33 & 6.13 & 26.9 & 10 & 0.785 & 9.22 & 15 & 5.53 & 9.47 & 4.8 & 0.375 & 4.42 & 14 & 0.260 & 13.7 & 10 & 1.61 & 8.39 \\
\hline OPC3 & 6.7 & 1.12 & 5.58 & 33 & 1.73 & 31.3 & 33 & 5.92 & 27.1 & 10 & 0.758 & 9.24 & 15 & 5.35 & 9.65 & 4.8 & 0.363 & 4.44 & 14 & 0.242 & 13.8 & 10 & 1.55 & 8.45 \\
\hline VPC1 & 6.7 & 1.01 & 5.69 & 33 & 1.55 & 31.5 & 33 & 5.29 & 27.7 & 10 & 0.678 & 9.32 & 15 & 4.78 & 10.2 & 4.8 & 0.324 & 4.48 & 14 & 0.224 & 13.8 & 10 & 1.39 & 8.61 \\
\hline VPC2 & 6.7 & 1.26 & 5.44 & 33 & 1.93 & 31.1 & 33 & 6.62 & 26.4 & 10 & 0.848 & 9.15 & 15 & 5.98 & 9.02 & 4.8 & 0.406 & 4.39 & 14 & 0.280 & 13.7 & 10 & 1.74 & 8.26 \\
\hline VPC3 & 6.7 & 1.11 & 5.59 & 33 & 1.71 & 31.3 & 33 & 5.86 & 27.1 & 10 & 0.751 & 9.25 & 15 & 5.29 & 9.71 & 4.8 & 0.359 & 4.44 & 14 & 0.248 & 13.8 & 10 & 1.54 & 8.46 \\
\hline CPC2 & 6.7 & 1.22 & 5.48 & 33 & 1.88 & 31.1 & 33 & 6.24 & 26.8 & 10 & 0.799 & 9.20 & 15 & 5.64 & 9.36 & 4.8 & 0.382 & 4.42 & 14 & 0.264 & 13.7 & 10 & 1.64 & 8.36 \\
\hline CPC3 & 6.7 & 1.05 & 5.65 & 33 & 1.60 & 31.4 & 33 & 5.48 & 27.5 & 10 & 0.702 & 9.30 & 15 & 4.95 & 10.0 & 4.8 & 0.336 & 4.46 & 14 & 0.232 & 13.8 & 10 & 1.44 & 8.56 \\
\hline
\end{tabular}

$\mathrm{CV}=$ calculated value, $\mathrm{TV}=$ table value, $\mathrm{D}=$ difference $(\mathrm{TV}-\mathrm{CV}), \mathrm{RAI}=$ recommended adult intake, No MSI standard for $\mathrm{K}, \mathrm{Mn}, \mathrm{Co}, \mathrm{Pb}, \mathrm{Cd}$ and $\mathrm{Ni}$, hence their MSI values were not calculated.

Table 5. Statistical analysis of the results from Table 1.

\begin{tabular}{|c|c|c|c|c|c|c|c|c|c|}
\hline & $\mathrm{UPC} \mathrm{OPC}_{1}$ & $\mathrm{UPC} / \mathrm{OPC}_{2}$ & $\mathrm{UPC} / \mathrm{OPC}_{3}$ & $\mathrm{UPC} \mathrm{VPC}_{1}$ & $\mathrm{UPC} \mathrm{VPC}_{2}$ & $\mathrm{UPC} \mathrm{VPC}_{3}$ & $\mathrm{UPC} / \mathrm{CPC}_{1}$ & $\mathrm{UPC} / \mathrm{CPC}_{2}$ & $\mathrm{UPC} \mathrm{CPC}_{3}$ \\
\hline$r_{x y}$ & 0.9999 & 0.9998 & 0.9998 & 0.9993 & 0.9951 & 0.9985 & 0.9943 & 0.9981 & 1.00 \\
\hline$r_{x y}^{2}$ & 0.9999 & 0.9996 & 0.9996 & 0.9987 & 0.9902 & 0.9971 & 0.9886 & 0.9963 & 1.00 \\
\hline$R_{x y}$ & 0.9835 & 0.9862 & 0.9943 & 0.9664 & 0.9895 & 1.01 & 0.9818 & 1.01 & 1.00 \\
\hline Mean $_{1}$ & 16.7 & 16.7 & 16.7 & 16.7 & 16.7 & 16.7 & 16.7 & 16.7 & 16.7 \\
\hline $\mathrm{SD}_{1}$ & 23.6 & 23.6 & 23.6 & 23.6 & 23.6 & 23.6 & 23.6 & 23.6 & 23.6 \\
\hline $\mathrm{CV} \%_{1}$ & 142 & 142 & 142 & 142 & 142 & 142 & 142 & 142 & 142 \\
\hline Mean $_{2}$ & 16.7 & 16.7 & 16.7 & 16.7 & 16.7 & 16.7 & 16.7 & 16.7 & 16.7 \\
\hline $\mathrm{SD}_{2}$ & 23.2 & 23.3 & 23.5 & 2.81 & 23.5 & 23.6 & 23.3 & 23.8 & 23.6 \\
\hline $\mathrm{CV} \%_{2}$ & 139 & 140 & 141 & 137 & 141 & 142 & 140 & 143 & 142 \\
\hline $\mathrm{C}_{\mathrm{A}}$ & 0.0051 & 0.0206 & 0.0209 & 0.0366 & 0.991 & 0.0541 & 0.107 & 0.609 & 0.00 \\
\hline IFE & 0.995 & 0.979 & 0.979 & 0.963 & 0.901 & 0.945 & 0.893 & 0.939 & 0.00 \\
\hline
\end{tabular}

$\mathrm{n}-2=14-2=12(\mathrm{df}), \mathrm{r}=0.01$ at $12(\mathrm{df})=0.661$. 
Table 6. Statistical analysis of the results from Table 1 (percentage energy values).

\begin{tabular}{|c|c|c|c|c|c|c|c|c|c|}
\hline & $\mathrm{UPC} \mathrm{OPC}_{1}$ & $\mathrm{UPC} \mathrm{OPC}_{2}$ & $\mathrm{UPC} \mathrm{OPC}_{3}$ & $\mathrm{UPC} \mathrm{VPC}_{1}$ & $\mathrm{UPC} / \mathrm{VPC}_{2}$ & $\mathrm{UPC} / \mathrm{VPC}_{3}$ & $\mathrm{UPC} / \mathrm{CPC}_{1}$ & $\mathrm{UPC} / \mathrm{CPC}_{2}$ & $\mathrm{UPC} \mathrm{CPC}_{3}$ \\
\hline$r_{x y}$ & 0.9999 & 0.9995 & 0.9996 & 0.9973 & 0.9866 & 0.9985 & 0.9943 & 0.9981 & 1.00 \\
\hline$r_{x y}^{2}$ & 0.9999 & 0.9990 & 0.9991 & 0.9464 & 0.9734 & 0.9971 & 0.9886 & 0.9963 & 1.00 \\
\hline$R_{x y}$ & 0.9898 & 1.01 & 0.9798 & 0.9699 & 1.09 & 1.01 & 0.9819 & 1.01 & 1.00 \\
\hline Mean $_{1}$ & 26.2 & 26.2 & 26.2 & 26.2 & 26.2 & 16.7 & 16.7 & 16.7 & 16.7 \\
\hline $\mathrm{SD}_{1}$ & 27.5 & 27.5 & 27.5 & 27.5 & 27.5 & 23.6 & 23.6 & 23.6 & 23.6 \\
\hline $\mathrm{CV} \%_{1}$ & 105 & 105 & 105 & 105 & 105 & 142 & 142 & 142 & 142 \\
\hline Mean $_{2}$ & 26.2 & 26.3 & 26.2 & 26.1 & 26.3 & 16.67 & 16.7 & 16.7 & 16.7 \\
\hline $\mathrm{SD}_{2}$ & 27.2 & 27.2 & 27.2 & 27.2 & 27.2 & 23.6 & 23.3 & 23.8 & 23.6 \\
\hline $\mathrm{CV} \%_{2}$ & 104 & 105 & 103 & 102 & 115 & 142 & 140 & 143 & 142 \\
\hline $\mathrm{C}_{\mathrm{A}}$ & 0.0029 & 0.310 & 0.030 & 0.0732 & 0.163 & 0.0541 & 0.107 & 0.609 & 0.00 \\
\hline IFE & 0.997 & 0.969 & 0.970 & 0.927 & 0.837 & 0.946 & 0.893 & 0.940 & 0.00 \\
\hline
\end{tabular}

$\mathrm{n}-2=14-2=12(\mathrm{df}), \mathrm{r}=0.01$ at $12(\mathrm{df})=0.661$.

Table 7. Statistical analysis of the results from Table 2.

\begin{tabular}{|c|c|c|c|c|c|c|c|c|c|}
\hline & $\mathrm{UPC} \mathrm{OPC}_{1}$ & $\mathrm{UPC} \mathrm{OPC}_{2}$ & $\mathrm{UPC} \mathrm{OPC}_{3}$ & $\mathrm{UPC} \mathrm{VPC}_{1}$ & $\mathrm{UPC} \mathrm{VPC}_{2}$ & $\mathrm{UPC} \mathrm{VPC}_{3}$ & $\mathrm{UPC} / \mathrm{CPC}_{1}$ & $\mathrm{UPC} / \mathrm{CPC}_{2}$ & $\mathrm{UPC} \mathrm{CPC}_{3}$ \\
\hline$r_{x y}$ & 0.9999 & 0.9999 & 0.9999 & 0.9999 & 0.9999 & 0.9999 & 0.9997 & 0.9999 & 0.9999 \\
\hline$r_{x y}^{2}$ & 0.9999 & 0.9999 & 0.9999 & 0.9999 & 0.9999 & 0.9999 & 0.9996 & 0.9999 & 0.9999 \\
\hline$R_{x y}$ & 0.7880 & 0.8100 & 0.7010 & 0.7010 & 0.8760 & 0.7750 & 0.9820 & 0.8260 & 0.7260 \\
\hline Mean $_{1}$ & 77.1 & 77.1 & 77.1 & 77.1 & 77.1 & 77.1 & 77.1 & 77.1 & 77.1 \\
\hline $\mathrm{SD}_{1}$ & 141 & 141 & 141 & 141 & 141 & 141 & 141 & 141 & 141 \\
\hline $\mathrm{CV} \%_{1}$ & 182 & 182 & 182 & 182 & 182 & 182 & 182 & 182 & 182 \\
\hline $\mathrm{Mean}_{2}$ & 60.7 & 62.5 & 60.4 & 54.1 & 67.5 & 59.8 & 74.6 & 63.6 & 55.9 \\
\hline $\mathrm{SD}_{2}$ & 111 & 114 & 110 & 98.5 & 123 & 109 & 138 & 116 & 102 \\
\hline $\mathrm{CV} \%_{2}$ & 182 & 182 & 182 & 182 & 182 & 182 & 185 & 182 & 182 \\
\hline $\mathrm{C}_{\mathrm{A}}$ & $1.80 \mathrm{e}-3$ & $1.48 \mathrm{e}-3$ & $1.58 \mathrm{e}-3$ & $1.49 \mathrm{e}-3$ & $1.61 \mathrm{e}-3$ & $1.45 \mathrm{e}-3$ & 0.0218 & $1.74 \mathrm{e}-3$ & $1.05 e-3$ \\
\hline IFE & 0.9982 & 0.9985 & 0.9984 & 0.9985 & 0.9987 & 0.9986 & 0.9782 & 0.9983 & 0.9990 \\
\hline
\end{tabular}

$\mathrm{n}-2=14-2=12(\mathrm{df}), \mathrm{r}=0.01$ at $12(\mathrm{df})=0.661$.

the UPC parameters being totally higher in values than the processed (fried plantain); meaning that for every unit increase in the UPC parameter, there was a corresponding increase of regression values in the processed (fried plantain) parameter. For both the UPC and fried plantains in the selected oils used, CV\% values were very high showing the high disparity in the overall concentrations of the parameters in the samples. For instance, in Table 5 (statistical analysis of values for the proximate composition) column 1 , the $r_{x y}$ was significant at $\mathrm{r}=$ 0.01 since $\mathrm{r}_{\text {cal }}=0.9999>\mathrm{r}_{\mathrm{Tab}}=0.661$ at $\mathrm{n}-2 \mathrm{df}(\mathrm{df}=$ degree of freedom $)$ meaning that significant differences existed in the proximate composition of the samples. The mean values were low at 16.7 (UPC) - $16.7\left(\mathrm{OPC}_{1}\right)$ with corresponding 
low values of standard deviation of 23.2 - 23.6. The $\mathrm{C}_{\mathrm{A}}$ was low at $0.0051 \%$ or $0.51 \%$ with a corresponding high value for IFE at $0.995 \%$ or $99.5 \%$. It is known that the higher the $\mathrm{C}_{\mathrm{A}}$, the lower the IFE and vice versa. Whilst CA is the error of prediction of relationship between two samples, the IFE is a reduction in the prediction of error of relationship. This meant that in this report the error of prediction was just $0.51 \%$ which could be regarded as low. Hence, the biochemical activities to be carried out by the UPC could also be carried out by the processed (fried plantain, $\mathrm{OPC}_{1}$ ). Same explanation goes for all the results in the other Tables.

\section{Conclusion}

The study showed that the selected vegetable oils (olive, refined palm olein and coconut) were good for frying plantains. The results for the unprocessed (fresh) and processed (fried) plantain chips [from the selected oils (use and re-use: first, second and third frying)] were found to be low in fat, carbohydrates, fibre, protein and ash. The highest energy contribution of the nutrients came from carbohydrates and least from protein. The utilization of energy value due to protein was fairly lower than the recommended value. Dominant macro minerals in the samples were: $\mathrm{Mg}, \mathrm{Ca}, \mathrm{K}, \mathrm{Na}$ and $\mathrm{P}$; nutritionally valuable trace minerals were: $\mathrm{Fe}, \mathrm{Cu}, \mathrm{Zn}, \mathrm{Se}, \mathrm{Mn}$ and $\mathrm{Ni}$; the biochemically toxic metals were $\mathrm{Cd}$ and $\mathrm{Pb}$ which were all significantly very low. Among the computed mineral ratios, $\mathrm{K} /(\mathrm{Ca}+$ $\mathrm{Mg}$ )] and $\mathrm{Zn} / \mathrm{Cu}$ met the acceptable ideal range. In the mineral safety index, none was found at the deleterious level. However, the highest level of nutrient compositions was observed in the products from the first-day frying compared to the products obtained from the first and second re-use of oil. For optimum nutrient preservation of fried plantain chips, re-use of oil for frying should be avoided as it leads to reduction in the nutritional contents (proximate and mineral compositions). The statistical analysis of the results shows that these values were high: $\mathrm{r}_{\mathrm{xy}}, r_{x y}^{2}, \mathrm{R}_{\mathrm{xy}}, \mathrm{CV} \%$ and IFE. The coefficients of alienation were low. The results were significantly different at $r=0.01$ and the prediction of biochemical relationship was also not difficult since the error of prediction was low at a range between $1.80 \mathrm{e}-3-0.609$ among all the samples.

\section{Conflicts of Interest}

The authors declare no conflicts of interest regarding the publication of this paper.

\section{References}

[1] FAO (2005) Production Yearbook for 2005, FAOSTAT Data. Food and Agriculture Organization of the United Nations Rome.

[2] Olorunda, A.O. and Adelusola, M.A. (1997) Screening of Plantain/Banana Cultivars for Import, Storage and Resistance to Disease and Pests. The International Symposium on Genetic Improvement of Bananas for Resistance to Disease and Pests, CIRAD, Montpellier, France, 7-9 September 1997. 
[3] Adeyeye, E.I., Adesina, A.J. and Faleye, F.J. (2018) Effects of Use and Re-Use of Selected Vegetable Oils on the Anti-Nutritional and Antioxidants Contents of Raw and Fried Plantain Chips. Note 1. CPQ Nutrition, 1, 1-29.

[4] Akinsanmi, A.O., Akinyemi, J.A. and Adefegha, A.S. (2015) Assessment of the Nutritional, Anti-Nutritional and Antioxidant Capacity of Unripe, Ripe and over Ripe Plantain (Musa parasidica) Peels. International Journal of Advanced Research, 3 , 63-7

[5] Penelope, N. and Ritu, N. (2003) Food Preparation Practices Can Affect Provitamin a Caroternoids Content and Bioavalability ILSI. Human Nutrition Institute, USA.

[6] Omotosho, O.E., Garuba, R., Ayoade. F., Adebayo, A.H., Adedipe, O.E. and Chinedu, S.N. (2016) Effects of Deep-Fat Frying Using Canola Oil, Soya Oil, and Vegetable Oil on the Proximate, Vitamins and Mineral Contents of Unripe Plantain (Musa paradisiaca). Jounal of Applied Sciences, 16, 103-167. https://doi.org/10.3923/jas.2016.103.107

[7] Mba, O.I., Dumant, M.J. and Ngadi, M. (2015) Influence of Palm Oil, Canola Oil, and Blends on Characteristics of Fried Plantain Crisps. British Food Journal, 117, 1793-1807. https://doi.org/10.1108/BFJ-04-2014-0155

[8] Erdman, J.W. and Schneider, A.G. (1994) Factors Affecting Nutritive Value in Processed Food. Romanian Journal of Food Science, 12, 111-136.

[9] Yang, J. and Gadi, R.L. (2008) Effects of Steaming and Dehydration on Anthocyanins, Antioxidant Activity, Total Phenols and Color Characteristics of Purple-Fleshed Sweet Potatoes (Ipomoea batatas). American Journal of Food Technology, 3, 224-234. https://doi.org/10.3923/ajft.2008.224.234

[10] Pearson, D. (1976) Chemical Analysis of Foods. 7th Edition, J. \& A. Churchill, London, 7-11.

[11] AOAC (2006) Official Methods of Analysis. 18th Edition, Association of Official Analytical Chemists, Washington DC.

[12] Varian Techtron Pty Ltd. (1975) Basic Atomic Absorption Spectroscopy: A Modern Introduction. Varian Techtron Pty Ltd., Springvale, Australia.

[13] Hatcock, J.N. (1985) Quantitative Evaluation of Vitamin Safety. Pharmacy Times, Cranbury, NJ, 104-135.

[14] Watts, D.L. (2010) HTMA Mineral Ratios: A Brief Discussion of Their Clinical Importance. Trace Elements Newsletter, 21, 1-3.

[15] Analytical Research Labs (2012) Basic Ratios and Their Meaning, 2225 W Alice-Avenue-Phoenix, Arizona 85021.

[16] Oloyo, R.A. (2001) Fundamentals of Research Methodology for Social and Applied Sciences. ROA Educational Press, Ilaro, Nigeria.

[17] Chase, C.I. (1976) Elementary Statistical Procedures. 2nd Edition, McGraw-Hill Kogakusha Ltd., Tokyo.

[18] Davey, K.R. (1989) A Predictive Model for the Combine Temperature and Water Activity on Microbial Growth during the Growth Phase. Journal of Applied Microbiology, 67, 483-488. https://doi.org/10.1111/j.1365-2672.1989.tb02519.x

[19] Naz, S., Ajum, M.A., Naqvi, S.A.H., Siddique, B. and Zulfiqar, M.A. (2018) Assessment of Proximate; Nutritional and Mineral Contents in Some Traditional Vegetables Consumed in Multan. Pakistan Journal of Agricultural Research, 31, 3375-3381. https://doi.org/10.17582/journal.pjar/2018/31.4.375.381

[20] Ukom, A.N. and Obi, J.A. (2018) Comparative Evaluation of the Nutrient Composition and Physicochemical Content of Selected Vegetables Consumed in Nigeria. In- 
ternational Letters of Natural Sciences, 71, 43-50.

https://doi.org/10.18052/www.scipress.com/ILNS.71.43

[21] Njinkoue, J.M., Foumedzo, R., Leng, M.M., Djopnang, J.D., Mawamba, A.D., Kana, M.M., Schweigert, F.J., Gouado, I. and Tchoumbougnang, F. (2019) Proximate Composition and Micronutrient Content of callianassa turnerana from the Wouri, Estuary, Cameroon. Journal of Food Research, 8, 32-40. https://doi.org/10.5539/jfr.v8n1p32

[22] Adeyeye, E.I. and Adubiaro, H.O. (2018) Proximate, Mineral, Vitamin Compositions, Mineral Safety Index and Mineral Ratios of the Flesh of Hetrosexual Pairs of Neopetrolisthes macalatus. Sustainable Food Production, 3, 46-62. https://doi.org/10.18052/www.scipress.com/SFP.3.46

[23] Elegbede, I.O. and Fashina-Bombeta, H.A. (2013) Proximate and Mineral Composition of Common Crap Species [Callinectes pallidus and Cardisoma armatum] of Badagrycreck, Nigeria. Poultry, Fisheries and Wildlife Sciences, 2, 110-114. https://doi.org/10.4172/2375-446X.1000110

[24] Akindahunsi, A.A. and Salawu, S.O. (2005) Phytochemical Screening and Nutrient-Antinutrient Composition of Selected Tropical Green Leafy Vegetables. African Journal of Biotechnology, 4, 497-501.

[25] Anita, S., Akpan, E.J., Okon, P.A. and Umoren, I.U. (2006) Nutritive and Antinutritive Evaluation of Sweet Potatoes (Ipomea batatas) Leaves. Pakistan Journal of $\mathrm{Nu}$ trition, 5, 166-168. https://doi.org/10.3923/pjn.2006.166.168

[26] NACNE (National Advisory Committee on Nutrition Education) (1983) Proposal for Nutritional Guideline for Health Education in Britain. Health Education Council, London.

[27] COMA (Committee on Medical Aspects) (1984) Committee on Medical Aspect of Food Policy: Diet and Cardiovascular Disease, HMSO, London.

[28] Bayeri, K.P., Aba, S.C., Otitoju, G.T. and Mbah, O.B. (2011) The Effects Ripening and Cooking Method. On Mineral and Proximate Composition of Plantain (Musa. sp. AAB cv Agbagba) Fruit Pulp. African Journal of Biotechnology, 10, 6979-6984.

[29] Lopez, H.W., Leenhardt, F., Coudray, C. and Remesy, C. (2002) Minerals and Phytic Acid Interactions: Is It Real Problem for Human Nutrition? International Journal of Food Science \& Technology, 37, 727-739. https://doi.org/10.1046/j.1365-2621.2002.00618.x

[30] Okwu, D.E. and Okwu, M.E. (2004) Chemical Composition of spondias mombim Linn Plants. Journal of Environment \& Sustainable Agriculture, 6,140-147.

[31] Javed, A. (2011) Proximate Composition, Minerals and Vitamins Content of Selected Vegetables Grown in Peshawear. Journal of the Chemical Society of Pakistan, 33, 118-122.

[32] Bergman, C., Gray-Scott, D., Chen, J.J. and Meacham, S. (2009) What Is Next to Dietary Reference Intakes for Bone Metabolism Related to Nutrients Beyond Calcium, Phosphorus, Magnesium, Vitamin D and Fluoride? Critical Reviews in Food Science and Nutrition, 49, 136-144. https://doi.org/10.1080/10408390701764468

[33] Murray, R.K., Granner, D.K., Mayes, P.A. and Rodwell, V.W. (2000) Harper's Biochemistry. 25thEdition, Health Profession Division, McGraw-Hill, New York.

[34] Nieman, D.C., Butlerworth, D.E. and Nieman, C.N. (1992) Nutrition, WmC. Brown Books Publishing, Dallas, TX, 227-312. 